\begin{tabular}{lll}
\hline Insan ve Toplum Bilimleri Dergisi \\
VAKIF ÜNIVERSITESI
\end{tabular}

\title{
Kur'ân ve Sünnet Bağlamında Avın Ekolojik Dengeye Olumsuz Etkisi Üzerine
}

Bahattin Dartma*

\section{Özet}

Yüce Allah kâinâtı, ölçülü bir şekilde içine tevdî ettiği nimetleriyle birlikte insan için yaratmıştır. Ancak insan, bu ölçülü nimetleri ölçüsüz bir şekilde kullanınca, çeşitli sorunlara neden olan tabiî dengenin bozulması hâdisesi ortaya çıkmıştır.

Tabiî dengenin korunmasında önemli unsurlardan biri de hayvanlardır. Dolayısı ile ekolojik sorunların çözümünde ve önlenmesinde hayvan unsurunu çok iyi değerlendirmek lazımdır.

Bu münasebetle, çeşitli ekolojik problemlere neden olan tabiî dengenin bozulmasının sebeplerinden biri de hayvan avlamaktır. Söz konusu problemin çözümünde hayvan avlamayı açlık, kıtlık ve yokluk gibi zarurî hallere hasretmek, sorunun çözümü için en tutarlı yol olarak görünmektedir.

Anahtar Kelimeler: Kur'ân, sunnet/hadis, av/avlanma, ekolojik denge, zaruri hal, fakirlik, açlık, kıtlık, yokluk, ruhsat, cevaz.

\section{Negative Impact of Hunt on Ecological Balance in the Context of the Qur'an and Sunnah} Abstract

Almighty God created the universe which was equipped with the measured blessings for the people. Yet, when the man use these measured blessings in a disproportionate manner, the problem of deterioration of the ecological balance which leads to many problems appear.

Of course, one of the most important factors in maintaining the natural balance is the animals. Therefore, in solving the ecological problems it is necessary to evaluate the animal element very well.

In this connection, hunting the animals is one of the reasons that cause degradation of the natural balance of animal and various ecological problems. In solving of the problem hunting the animal is favoured in the cases of inevitable conditions such as hunger, famine and poverty. This seems to be the most consistent way.

Keywords: Qur'ân, sunna/hadith, hunt/hunting, ecological balance, vital status, poverty, hunger, famine, poverty, permissibility, permission, permitted.

* Prof. Dr., Marmara Üniversitesi İlahiyat Fakültesi, İstanbul/Türkiye, bahagani@gmail.com 


\section{Giriş:}

Yüce Allah, mükemmel bir şekilde inşâ ettiği kâinâtı,1 en güzel sûrette yarattığı insanın² istifadesine sunmuştur. Bu konuda Kur'ân'ın ifadeleri çok açık ve nettir:

"Yeryüzünde ne varsa hepsini sizin için yarattı"3

"Allah (cc), yeryüzünde bulunan her şeyi... hizmetinize sunmuştur."

Öte yandan Kur'ân, kâinâttaki bu imkanların ölçülü olduğunu da bildirmiştir:

“Arzı da yaydık... orada hikmetle ölçülmüss olarak her türlü nebatı yetiştirdik... Hiçbir şey yoktur ki onu meydana getiren hazinelerin anahtarlarl elimizde olmasın. Ama biz onu bel[ir]li bir ölçüyle indiririz" ${ }^{5}$

Dolayısı ile bu ölçülü nimetlerin yine ölçülü bir şekilde kullanılması gerekmektedir:

"Yeyin için, fakat israf etmeyin; çünkü Allah, israf edenleri sevmez"6

Hatta bu konuda ölçüsüz hareket etmek, şeytana kardeş olmakla eşdeğer sayılmıştır:

"Akrabaya, yoksula ve yolda kalmıs yolculara haklarını ver, fakat saçıp savurma! Çünkü (gereksiz yere mallarını) saçıp savuranlar, şeytanların kardeşleri olmuşlardır...."

Yüce Allah tarafindan verilen imkanların ölçülü kullanılması gerektiği konusu sünnette de şöyle yer almıştır:

"Resûlullah (sav), Sacd abdest alırken ona uğradı. Sacd'ın abdest alırken çok su kullandiğını görünce, 'bu israf da ne[dir]?' dedi. Sacd'in, abdestte israf olur mu? demesi üzerine Allah Resûlü şöyle buyurdu: Evet (olur), akmakta olan bir nehrin yanında olsanız bile!"'8

1 Mülk(67), 3 .

2 Tin (95), 4.

3 Bakara (2), 29.

$4 \operatorname{Hacc}(22), 65$. Konuya ilişkin başka âyetler için meselâ bkz., Hicr (15), 20, 85; $\operatorname{Nahl~(16),~} 12$ 13; Lokmân (31), 20; Mü'min (40), 80; Câsiye (45), 13; Ahkâf (46), 3; Rahmân (55), 10; Mülk (67), 15; Abese (80), 24-32; Nâziât (79), 30-33.

$5 \operatorname{Hicr}(15), 19,21$. Konuya ilişkin başka âyetler için meselâ bkz., Alâ (87), 2-3ç

6 A'râf (7), 31. Âyetin geniş açıklaması için bkz., Reşîd Rızâ, Muhammed, Tefsîru'l-Kur'âni'lHakîm eş-Şehîr bi Tefsîri'l-Menâr, 2. (ofset) bask1, Dâru'l-Ma'rife, Beyrut, VIII, 384. Konuya ilişkin olarak başka bir âyet için bkz., Furkân (25), 67.

7 İsrâ'(17), 26-27. Konumuz açısından burada 'şeytanın kardeşleri olmaktan' maksat, "aşırı bir tüketim ekonomisi uygulamak ve yersiz harcama yapmak suretiyle ekolojik dengenin bozulmasina sebebiyet verme" olabilir.

8 İbn Mâce, Ebû Abdillah Muhammed b. Yezîd el-Kazvînî, Sünenu İbn Mâce, İstanbul, 1981, Tahâret, 48. 
Ancak insanlar, dengeli bir şekilde yaratılan kâinâtın bu dengesini korumaya yönelik gereken hassasiyeti göstermemişler, ${ }^{9}$ dolayısı ile çeşitli çevre sorunlarına sebebiyet vermişlerdir:

"Insanların elleriyle kazandiklarl/yapıp ettikleri yüzünden, karada ve denizde (yani bütün yer kürede) bozukluk/olumsuzluk çıktı. Belki dönerler diye (Allah) onlara, yaptıklarinin bir kisminı tattırıor."

Âyette geçen "fesâd" kelimesi sözlükte, "itidal sınırının dışında olmak, salâhın zıdd1, kuraklık ve kıtl1k" "l1 gibi anlamlara gelmektedir. Buna göre âyeti, işlemekte olduğumuz konu açısından şöyle anlamamız mümkündür: İnsanlar, Yüce Allah'ın verdiği imkanları, dînî ve ahlâkî verileri dikkate almadan istedikleri şekilde/keyfî olarak kullanırlar. Bu yanlış uygulama neticesinde de karada ve denizde tabiî denge bozulup 'kuraklık ve kıtlık' gibi zararı başta insan unsuru olmak üzere bütünüyle mahlûkâta dokunan ekolojik dengenin ${ }^{12}$ bozulması sorunu ortaya çıar.

Hatta insanlar bu yanlış tutum ve davranışlarıyla hem kendi geleceklerini ve hem de gelecek nesillerin hayatlarını tehlikeye sokarlar:

"Fakat insan, devaml suç işleyerek ilerisini berbat etmek ister. Klyâmet günü nerede? diye sorup durur." 13

Kanaatimize göre âyette konuyla ilgili olarak şu husus anlatılmak istenmiş olmalıdır: İnsanlar ilâhî kıstaslara aykırı olarak düşünce ve davranış geliştirip sergilerler. Onların yaptıkları bu yanlışlıklar sonucu ortaya çıkan problemler, yine kendilerine, kıyâmet gününü aratacak derecede zorluklar yaşatır ve acılar tattırır. Yapılan bu hataların içine, insanların sebep olduğu ekolojik dengenin bozulması problemi de dahil edilmelidir. Çünkü sözü edilen problem, hayatın tabiî akışını aksatarak bütünüyle canlıların hayatını tehdit eden, başka bir ifadeyle onların yaşama haklarını ortadan kaldıran çok tehlikeli bir problemdir.

Dolayısı ile biz bu küçük çaplı çalışmamızda, tabiî dengeye zarar veren etkenlerden biri olan hayvan avlama konusunu, Kur'ân ve Sünnet bağlamında çok muhtasar bir şekilde ele almaya çalışacağız.

Bu kısa girişten sonra şimdi meselenin önemini kavramak için önce Kur'ân ve Sünnette hayvanlara verilen değeri ortaya koyan birkaç veri aktaralım:

9 A'râf (7), 56; Kasas (28), 77.

10 Rûm (30), 41.

11 İbn Sîde, Ebû'l-Hasan Alî b. İsmâîl, el-Muhkem ve'l-Mühîdu'l-Azamu, (thk., Abdu'l-Hamîd el-Hindâvî), Dâru'l-Kütübi'l-İlmiyye, 1. bask1, Beyrut, 1321/2000, VIII, 458-459 (F-S-D mad.); Âsım Efendi, Kâmûs Tercemesi, İstanbul, I, 1240 (F-S-D mad.).

12 Ekolojik denge: İnsan, hayvan ve bitkilerin tabiatta hayatlarını sürdürebilmesi ve birlikte yaşayabilmesi için birbirlerini tamamlamaları ve birbirlerinden istifade etmek istemeleriyle oluşan tabiî dengedir. http://www.delinetciler.net/forum/ekoloji-ve-cevre-sorunlari/127553-ekolojik-denge-nedir.html. (Erişim:09.07.2012.)

13 Kiyâme (75), 5-6. 


\section{Kur'ân ve Sünnette Canlılara/Hayvanlara Atfedilen Değer}

\section{Kur'ân-ı Kerîm:}

Herşeyden önce Kur'ân, kâinâtta hiçbir şeyin boş yere yaratılmadığını vurgulamaktadır:

"Göğ̈̈, yeri ve ikisi arasındakileri boş yere yaratmadı..." "14

"Biz gökleri yeri ve bunlar arasında bulunanları hak ile yarattı..." 15

$\mathrm{Bu}$ cümleden olarak Kur'ân, hayvanların bazılarının adlarını zikredip ${ }^{16}$ tıpkı insanlar gibi birer ümmet/topluluk olduklarından bahsetmektedir:

"Yeryüzünde gezen her türlü canlı ve gökte iki kanadiyla uçan her türlü kuş, sizin gibi bir topluluktan başka bir şey değildir." 17

Hayvanlar, biyolojik ve fizikî açıdan tıpkı insanlar gibi, bir şekilde yaratılarak hayata kavuşturulmuş, bir nizam altına alınmış, rızıkları ve ömürleri takdir edilmiş olup belirli bir vakte kadar yer-içer, çoğalır, yaşar ve nihâyet ölürler. ${ }^{18}$ Onların bu tür özellikleri yanında başka hususiyetleri de vardır. Yapılan araştırma, deney ve gözlemler, insanlar arasında olduğu gibi hayvanlar arasında da maddi ve manevi olarak bir takım düzen, kâide ve kuralların bulunduğunu ortaya çıkarmıştır. Nitekim Yüce Allah şöyle buyurmaktadır:

"(Süleyman ve orduları) karınca vadisine geldikleri zaman bir karınca, "ey karıncalar dedi, yuvanıza girin ki, Süleyman ve orduları, farkında olmadan sizi ezmesinler"19

$\mathrm{Bu}$ âyet, canlılar arasında fevkalâde bir iletişimin varlığını göstermesi bakımından oldukça dikkat çekicidir. ${ }^{20}$ Hatta hayvanların, insanlar gibi akı1, his, duyu, âlet kullanma vb. yetenek ve özellikleri bulunmaktadır. ${ }^{21}$ Son zamanlarda hayvan eğiti-

$14 \operatorname{Sad}(38), 27$.

15 Hicr (15), 85. Benzer manada başka bir âyet için bkz., Ahkâf (46), 3.

16 Meselâ bkz., Bakara (2), 67, 259; 'Âl-i İmrân (3), 14; Enâm (6), 144, 146; A'râf (7), 107; Enfâl (8), 60; Yûsuf (12), 13, 43; Nahl (16), 8, 68; Tâhâ (20), 20; Enbiyấ' (21), 78; Hacc (22), 73; Neml (27), 18; Ankebût (29), 41; Cuma (62), 5; Ğâşiye (89), 17. Kur'ân'da adları geçen hayvanlar ve bunların bazı karakteristik özellikleri hakkında geniş bilgi için bkz., Kârim es-Seyyid Ğanîm, Abdulazîm Muhammed el-Cemal, el-Cerâd fî'l-Kur'âni'l-Kerîm ve'l-ìlmi'l-Hadîs, 1. bask1, Kahire, 1988/1409; Ahmed Behcet, Kisasu'l-Hayevân fî'l-Kur'ân, Dâruşşurûk, 4. bask1, 2000/1420; Zağlûl Râğıb - Muhammed Neccâr, el-Hayevân fî'l-Kur'âni 'l-Kerîm min Âyâti'l-İc câzi'l-İlmî, Dâru'l-Macrife, Beyrut, 2006.

$17 \operatorname{Enâm}(6), 38$.

18 Fahreddîn er-Râzî, Ebû Abdillah Muhammed b. Ömer, et-Tefsîru'l-Kebîr, Daru'l-İhyâ'i't-Türâsi'l-Arabî, 3. bask1, XII, 213, 214; Hamdi Yazır, Hak Dini Kur'ân Dili, İstanbul, 1979, III, 1919.

19 Neml (27), 18.

20 Bu konuda daha geniş bilgi için bkz., İrfan Yılmaz, Hayvanların Dilinden, İzmir, 2005; a. mlf., Hayvanlar Konuşuyor, İzmir, 2005.

21 Nesrin Çobanoğlu, , "Hayvan Haklarının Tarihsel Gelişiminin Biyoetik Yansımaları", Bilim ve Ütopya, 116. say1, Şubat 2004, s. 73. 
mi alanında gelinen aşama, onların bu tür hususiyetlere sahip olduklarını kanıtlar niteliktedir.

\section{Hadis/Sünnet:}

Hadislerde de hayvanlara bir hayli önem verildiği görülmektedir. Resûlullah (sav) haklı bir neden olmaksızın canlıların öldürülmesini yasaklamıştır:

"Haksız yere öldürülen her canl, klyâmet günü (kendisini) öldürenden davacı olacaktır"22

"Ruhu/canı olan hiçbir şeyi (atış) hedef[i] yapmayınız"’3

Aksi halde bunun, hem maddî ve hem de manevî olarak bir cezâ'î mü' eyyidesinin olduğu bildirilmiştir:

"Bir kadına bir kedi yüzünden azab edildi. Kediyi ölünceye kadar hapsetmiş, bu esnada onu ne doyurmuş, ne sulamış ve ne de yerin haşerâtından yemesine müsaade etmiş; bu yüzden de cehenneme girmiştir/atılmıştır. "24

"Hacc esnasında ihramlı birinin devesi, bir deve kuşu yuvasina basarak yumurtaların kirar. Durum Hz. Peygamber'e intikal eder. Hz. Peygamber o kimsenin, her bir yumurtaya karşılı bir gün oruç tutması ve bir miskînilfakiri de doyurması gerektiğine hükmeder." 25

Dinimizde hayvanlara o kadar önem verilmiştir ki, onların boş yere öldürülmemeleri gerektiği emri ile yetinilmemiş, onlara ezâ ve cefâ edenler lanetlenmiştir:

"Săg iken hayvandan kesilen şey ölü[hükmünde olup haram]dır, (o kesilen kısmı hiç kimse yemesin)"’26

22 Celâleddîn Abdurrahmân b. Ebî Bekr Suyûtî, el-Câmicu's-Sağîr fì Ehâdî̀i'l-Beşîri'n-Nezîr, Dâru'l-Fikr, 1. bask1, Beyrut, 1401/1981, II, 512 (hadis no., 8025).

23 Ahmed b. Hanbel, Müsned, İstanbul, 1982, I, 340, 345; Ebû'l-Huseyn Müslim b. El-Haccâc Müslim, Sahîhu Müslim, İstanbul, 1981, Sayd, 12, 58/1957; Zebâ’ih İbn Mâce 10; Taberânî, Ebû'l-Kâsım Süleymân b. Ahmed, el-Mucemu'l-Kebîr, (thk., Hamdî Abdulmecîd es-Selefî) 2. bask1, Mektebetu İbn Teymiye, Kâhire, XX, 386 (hadis no., 905). Konuya ilişkin başka hadisler için meselâ bkz., Ahmed b. Hanbel, II, 197, 210; Ebû Abdirrahman Ahmed b. Şuayb Nesâ'î, Sünenu'n-Nesâ '̂̀, İstanbul, 1981, Sayd, 34, Zahâyâ, 42; Taberânî, el-Mucemu'l-Evsat, (thk., Târık b. Ivezullah b. Muhammed - Abdulmuhsin b. İbrahim el-Huseynî), Daru'l-Haremeyn, Kahire, 1995/1415, IV, 104 (hadis no., 3716), IX, 111-112 (hadis no., 9277); a. mlf., $M$. el-Kebîr, XI, 220 (hadis no., 11719), 352 (hadis no., 12263), 354 (hadis no., 12269), XXII, 297 (hadis no., 757); Suyûtî, II, 630 (hadis no., 8910).

24 Muhammed b. İsmâîl Buhârî, Sahîhu'l-Buhârî, İstanbul, 1981, Müsâkât, 10, Enbiyâ', 52; Müslim, el-Birr ve's-Sila, 133, Selâm, 151/2242.

25 Ahmed b. Hanbel, V, 58.

26 Ebû Îsâ Muhammed b. Îsâ b. Sevrate Tirmizî, Sünenu't-Tirmizî, İstanbul, 1981, Etime, 4; Ahmed b. Ali el-Mevsılî Ebû Yaclâ, Müsnedu Ebî Yaclâ el-Mevsılî, (thk., Mustafa Abdulkâdir Atâ), 1. bask1, Beyrut, 1998/1418, II, 22 (hadis no., 1446); M. Taberânî, el-Evsat, VIII, 51 (hadis no., 7932). Son parantezin içindeki kısım Taberânî’den ilave edilmiştir. 
"Nebî (sav), hayvanlara işkence yapanaleziyet edene lanet etmiştir"'27

Dahası hayvanların aldatılmaları, ${ }^{28}$ korkutulmaları, rahatsı edilmeleri ${ }^{29}$ ve birbirlerine karşı kışkırtılmaları ${ }^{30}$ da uygun bir davranış olarak görülmemiştir. Onların beslenmelerine özen gösterilmesi ${ }^{31}$ ve fitratlarına uygun işlerde istihdam edilmeleri ${ }^{32}$ önerilmiştir.

Konuyla ilgili olarak Fuzayl b. İyâz'nn şu sözü kayda değerdir:

"İnsan, ihsan ve iyiliğin her şeklini yerine getirse, fakat sadece kümesindeki tavuğa kötülük etse, yine de muhsin denilen iyi insanlardan sayılmaz." ${ }^{33}$

Bütün bu vb. emir ve tavsiyeler sonucu olmalı ki İslâm beldelerinde hayvanlara hep şefkat ve merhametle yaklaşılmış ve hatta erken denebilecek bir dönemde hayvan hakları gündeme getirilmiştir. Meselâ İbn Abdisselâm (v. 660/1262) 'hayvanlara, barınma ve beslenme gibi ihtiyaçlarının itina ile karşılanarak gereken ilginin gösterilmesi, haddinden fazla yük yükletilmemesi, gerek insanlar ve gerekse hem cinsleri tarafından hiçbir şekilde rahatsız edici davranışlarda bulunulmamasi/eziyet edilmemesi, kesilmek istendikleri takdirde usulüne uygun olarak kesilmeleri, yavrularının gözleri önünde kesilmemesi gerektiği... ${ }^{34}$ gibi günümüzde bile yeteri kadar riâyet edilmeyen hayvan haklarından bahsetmektedir.

Hatta İslâm coğrafyasında hayvanlara mahsus hastahaneler bile te'sîs edilmiştir. $^{35}$

Müslümanların, hayvanlara karşı sergiledikleri -diğer din mensuplarında görülmeyen ${ }^{36}$ - bu takdîre şâyân tutum ve davranışlar, yabancıların bile dikkatini

27 Buhârî, Sahîh, Zebâ'ih, 25; Abdullah b. Muhammed İbn Ebî Şeybe, el-Müsannef fì'l-Ehâdîsi ve'l-Âsâri, (thk. ve taclîk, Secîd Muhammed el-Lehhâm), Dâru'l-Fikr, 1. bask1, Beyrut, 1409/1989, es-Sayd, 36/3 (IV, 632), 36/4 (IV, 633); Suyûtî, II, 409 (hadis no., 7283). Konuya ilişkin başka hadisler için bkz., İbn Ebî Şeybe, el-Edeb, 103/1 (VI, 166), es-Sayd, 43/2, 5 (IV, 639, 640); Ebû Bekr Ahmed b. el-Huseyn b. Ali Beyhekî, Şu'abu'l-Îmân, (thk., Ebû Hêcir Muhammed es-Sacîd b. Besyûnî Zeğlûl), 1. bask1, Dâru'l-Kütübi'l-İlmiyye, Beyrût, 1410/1990, VII, 485; Suyûtî, I, 146 (hadis no., 953, II, 648 (hadis no., 9043).

28 Suyûtî, II, 626 (hadis no., 8882).

29 Süleymân b. el-Eş̧as Ebû Dâvûd, Sünenu Ebî Dâvûd, İstanbul, 1981, Cihâd, 112; Taberânî, M. el-Kebîr, III, 131 (hadis no., 2896).

30 Tirmizî, Cihâd, 30; Ebû Yaclâ, II, 462 (hadis no., 2503); Suyûtî, II, 683 (hadis no, 9337).

31 Suyûtî, II, 508 (hadis no., 8001).

32 Buhârî, Sahîh, Fezâ'ilu's-Sahâbe, 5; Müslim, Fezâ'ilu's-Sahâbe, 13/2388.

33 İsmet Sungurbey, Hayvan Haklarl, 2. bask1, İstanbul, 1993, s. 281.

34 Ebû Muhammed 'İzzuddîn Abdul'azîz İbn Abdisselâm, Kavâidu'l-Ahkâm fì Mesâlihi'l-Enâm, Beyrut, 1990/1410, (I. cüz), s. 121.

35 Guer, Moeurset usages des Turcs, Paris, 1746-7, I, 217-221, (bkz., İsmâil Hâmi Danişmend, Garb Menbalarına Göre Eski Türk Seciyye ve Ahlakı, 3. bask1, İstanbul, 1982, s. 135).

36 Meselâ bkz., Aubrey Rose, Judaism and Ecology, (Yahudilik ve Ekoloji), (Türkçesi, Mehmet Demirhan), İstanbul, 1997, s. 60, 94. 
çekmiştir. Şimdi örnek olarak bunlardan bir-ikisinin sözlerini nakledelim:

A. L. Castellan konuya ilişkin olarak şöyle der:

"Türkler, ihtiyarlarla çocuklara hürmet ve riâyet gösterirler ve hatta iyiliklerini hayvanlara bile teşmil ederler. Leyleklerle kırlangıçlar hiçbir kovulma tehlikesine uğramamak şartıyla Türk evlerinin üzerlerine yuvalarını yapabilirler. Hatta bu vaziyet (durum) Allah'ın bir inâyeti ve ihsanı, her türlü felaket ve musîbete karşı s1yâneti (himâye/koruma vesilesi) sayılır...

Limana hubûbat (tahıl) getiren gemilere kumruların binlercesi birden üşüşüp gümrüğün harc olarak aldığı miktardan belki daha fazlasını haraca keserler. Evler yapılırken hayvanların susuz kalmaması için icab eden yerlere yalaklar konulur ve duvarlarda arabeskler (motifleri girift, iç içe geçme şeklinde olan bezeme tarzı) ile süslü küçük köşkler kurularak oralara gelip kuluçkaya yatmak isteyen kuşlara yuvalar temin edilir." 37

Mouradgea d'Ohsson ise şunları söylüyor:

"Hayrât ve hasenât hayvanlara bile şâmildir. Hiç kimse onlara eziyet etmeye kalkışmaz. Eğer bir at, bir katır veyahut bir deve sahibi, hayvana haddinden fazla yük taşıtacak olursa, zâbıta memurları gaddarlığına (zulmüne/haksızlığına) mânic (engel) olmak ve fazla yorulan hayvanı dinlendirmeye mecbur etmek selâhiyetine hâizdir...."38

\section{Av ve Ekolojik Denge}

Buradaki "hayvan avlama" ifadesinden maksadımı, eti yensin veya yenmesin, şahsî veyahut da ticârî amaçla yapılsın, hangi usül ve yöntemle ve hangi zaman ve zeminde gerçekleştirilirse gerçekleştirilsin, bilinçli-bilinçsiz, küçük-büyük olsun, canlılık özelliği taşıyan her tür yaban hayvanının yaşamına son vermektir.

Görüldüğü gibi "hayvan avlamanın” çerçevesini oldukça geniş tuttuk. Sebebi ise bu konuda en küçük bir yanlış eylemin dahi çevreye az veya çok zarar verecek mahiyette olmasıdır. Çünkü bu araştırmanın amacı, söz konusu yanlış eylemin fitrî dengeye verdiği zararı ortaya koyup önlenmesi gerektiğini vurgulamaktır. İşte şu âyetler, kâinâttaki bu dengeye dikkat çekmektedirler:

"Gögü yükseltti, ölçüyü/dengeyi koydu. Artık dengeye tecavüz etmeyin. Dengeyi doğru tutun/kollayın, bozmayın. "39

37 A. L. Castellan, Lettres sur la Grèce, I'Hellespont et Constantinople, Paris, 1811, II, 227, (bkz., Danişmend, s. 189).

38 Mouradgea d'Ohsson, Tableau Gènèral de I'Empire Othoman, Paris, 1791, I, 307-309), (bkz., Danişmend, s. 188).

39 Rahmân (55), 7-9. 
"Gerçekten, her şeyi bir ölçü ve dengede yarattık"40

Kâinât, İlâhî İrâde tarafından kurulan tabiî dengesini koruyarak işleyişine devam ederse herhangi bir çevre sorunu ortaya çıkmaz. Ancak insanların itidal s1nırını aşan müdahalesi sonucu bu dengeli işleyiş bozulursa işte o zaman çevresel sorunlar ortaya çıkar ve neticede tahammül gücünün üzerine çıkan zorluklar meydana gelir.

İşte kâinâtın tabiî dengesini bozan olumsuz davranışlardan biri de şüphesiz ki hayvan avlamaktır. Hayvan avlamanın ekolojik problemlere yol açtığı, çevre hakkında inceleme yapan bütün araştırmacıların ve çevreye karşı duyarlı olan hemen herkesin ortak görüşüdür. O halde bu kısa bilgilerden sonra şimdi -dînî açıdan- hayvan avlama konusuna geçebiliriz.

Şunu hemen ifade edelim ki, gerek hadis ve gerekse fikıh kitaplarının ilgili bölümlerinde, mutlak olarak av yapmayı emreden kesin bir ifadenin olduğunu söylemek pek mümkün görünmemektedir. Bu bölümlerde sadece, av yapılmak istendiğinde bu avın helal olması için nasıl hareket edileceğine dair bilgiler yer almaktadır. Gerek Resûlulah(sav)'in ve gerekse büyük sahâbîlerin avla uğraştıkları vârid değildir. ${ }^{41}$ Aksine Resûlullah(sav)'in, av yapmayı tasvip etmediğine dair beyanları vardır. Konuya ilişkin olarak bir hadisinde o şöyle buyurmaktadır:

"Çölde yaşayan kaba, av peşinde koşan gafil olur..." "42

Hayvan avlamak, onların Allah'1 tesbih etmelerini engellemesi nedeniyle de zararlı görülmüştür:

"Avlanan her av ve kesilen her ağaç, (Allah'ı) tesbih[etmey]i yok etmeden başka bir şey değildir." "43

Ayrıca ihramlı iken hayvan avı yasağı Kur'ân'da da vardır:

"Ey inananlar, ihramda iken av hayvanı öldürmeyin. Sizden kim kasden/bilerek onu öldürürse üzerine, öldürdüğ̈̈ o hayvanın dengi olan bir hayvan cezası vardır...",44

Durum böyle olmakla birlikte İslâm'da hayvan avlamanın haram olduğunu söylemek mümkün değildir. Çünkü şu âyetler -ihramlı olma hali dışında- avın

40 Kamer (54), 49. Konuya ilişkin başka âyetler için meselâ bkz., Şûrâ (42), 27; Talak (65), 3.

41 Huccetullâhi'l-Bâliğa Şâh Veliyyullah ed-Dıhlevî, (İslâm Düşünce Rehberi), (Türkçesi, Mehmed Erdoğan), İstanbul, 2003, II, 166.

42 Ahmed b. Hanbel, I, 357; Ebû Dâvûd, Sayd, 24, 25; Tirmizî, Fiten, 69; Taberânî, M. el-Evsat, I, 176 (hadis no., 556). Hadîsin, hayvan avlamanın doğru olmadığı yönündeki izahı için bkz., Ebû'l-'Alâ Muhammed Abdurrahmân b. Abdirrahîm Mübârekfûrî, Tuhfetu'l-Ahvezî bi Şerh-i Câmici 't-Tirmizî, 1. bask1, Beyrut, 1410/1990, VI, 440. Bu konuda başka bir hadîs için ayrıca bkz., Muhammed b. İsmâîl Buhârî, el-Edebu'l-Müfred, (thk., Muhammed Fu'âd Abdulbâkî), 3. bask1, Dâru'l-Beşâ'iri'l-İslâmiyye, 1989/1409, 404/905 (s. 312).

43 Suyûtî, II, 498 (hadis no., 7928).

44 Mâ'ide (5), 95. Konuya ilişkin olarak ayrıca bkz. Mâ'ide (5), 1. 
helâl olduğunu sarâhaten ortaya koymaktadır:

"Ey iman edenler! Allah'ın (koyduğu, dinî) işaretlerine, haram aya, (Allah'a hediye edilmiş) kurbana, (ondaki) gerdanlıklara, Rablerinin lütuf ve rızasını arayarak Beyt-i Haram'a yönelmiş kimselere (tecavüz ve) sayglsızlık etmeyin. Ihramdan çıkınca avlanabilirsiniz..." 45

"Hem kendinize, hem de yolculara bir geçimlik olmak üzere deniz avı ve yiyeceği size helâl kılındı. İhrâmda olduğunuz sürece size kara avı yasaklandı. Huzûruna toplanacağınız Allah'tan korkun!"46

Ancak bugün dünyanın içinde bulunduğu çevresel sorunlar ve bu sorunların çözümünde hayvanların olumlu etkileri ve katkıları dikkate alındığında şunu söyleyebiliriz: Esâsen dînimizde av yapmak emredilmemiş ona, ruhsat verilmiştir. Ancak bu ruhsatın, keyfî olarak değil, 'zaruri bir durum hasıl olduğunda', daha açık bir ifadeyle, 'fakirlik, açlık, kıtlık, darlık, sefillik ve yok[sul]luk' gibi zorunlu hallerde ve ihtiyacı giderecek kadar kullanılması daha doğru ve isabetli görünmektedir. $\mathrm{Bu}$ itibarla yukarıdaki ikinci âyette geçen "bir geçimlik olmak üzere" ifadesini, "ihtiyac1, asgari seviyede giderecek miktar" olarak anlamak mümkündür.

Yeri gelmişken şunu da belirtmekte fayda vardır ki, her ne kadar balık gibi çoğalma/üreme oranları hayli yüksek olan ve bu nedenle bol miktarda bulunan canlıların avlanmasinda ve hatta bu hususta cevaz/ruhsat sinırının biraz daha geniş tutulmasında herhangi bir sakıncalı durumun söz konusu olmayabileceği akla gelmekle beraber yine de ölçülü ve bilinçli avlanmakta fayda vardır. Çünkü bilinçsiz, zamansız ve gereğinden fazla balık avlanmasının, bazı balık türlerinin azalmasına, bazılarının da bütünüyle nesillerinin tükenmesine sebep olduğu bilinmektedir.

Ayrıca hayvan avlamak ekolojik dengeyi bozduğu gibi -ki bu husus yukarıda belirtilmişti- manevî açıdan da şefkat, merhamet, acıma hissi vb. duyguların kaybolmasına sebebiyet vererek kalbi katılaştırmaktadır. ${ }^{47}$

\section{Avlanmanın Tabiî Dengeye Olumsuz Etkisine Dair Örneklemeler}

1. Bir zamanlar Samsun'da köylülere toplattırılan kurbağalar Avrupa'ya ihraç edilmiş, bu yüzden doğal denge bozularak Samsun sivrisinek istilasina maruz kalmıştır. $^{48}$

Eğer köylüler, "Resûlullah kurbağanın öldürülmesini yasakladı ve şöyle buyurdu: Onun viraklaması (Allah'ı) tesbihtir"49 mesajının ne anlama geldiğini

45 Mâ'ide (5), 2.

46 Mâ'ide (5), 96.

47 İbrahim Canan, Âyet ve Hadisler Işığında Çevre Ahlakı, İstanbul, Şubat 1995, s. 124. Konuya ilişkin olarak ayrıca bkz., Şâh Veliyyullah ed-Dıhlevî, II, 460.

48 Sungurbey, s. 174 (dipnot).

49 Taberânî, M. el-Evsat, IV, 104 (hadis no., 3716). 
öğrenip gereğini yapsalard1, ekolojik dengeye zarar veren böyle bir işe belki hiç teşebbüs etmeyeceklerdi.

2. Konya'nın Yalıhüyük ilçesinde (2010 yılında), bilinçsiz bir şekilde anız yakılması nedeniyle, fare ile beslenen, başka bir ifadeyle fare sayısını dengeleyen yılan ve gelincik gibi canlıların ölmesi sonucu ekolojik denge zarar görerek tarla fareleri çoğalıp arpa ve buğdayın ekildiği 30 bin dekarlık alandaki bu ürünlere büyük zararlar vermişlerdir. Tarlalarda yüzde 40-50 oranında ürün kaybı olmuştur. Dekarında 400-500 kilogram verim alan çiftçi, farelerin istilasına uğrayan arazisinde dekarda sadece 100 kilogram ürün almış, bazı yerlerde ise hiç alamamıștır. ${ }^{50}$

Eğer anız yakanlar, yukarıda da zikredilen Resûlullah(sav)'in şu, "haksız yere öldürülen her canlı, klyâmet günü (kendisini) öldürenden davacı olacaktır" hadisinin ne anlam ifade ettiğini düşünüp gereğine göre hareket etselerdi, tabiî dengeye zarar veren böyle bir işe belki hiç girişmeyeceklerdi.

3. Son y1llarda Türkiye'mizde kene 1sırması sonucu meydana gelen Kırım Konga Kanamalı Ateşi nedeniyle bazı insanlar hayatını kaybetmiş ve hala kaybetmektedir. Bunun nedeni ise, orman ve tarım alanlarında aşırı ve bilinçsiz avlama ve ilaçlama esnasında kuşlar gibi kene ile beslenen yüzlerce tür canlının yok olmasıdır. Yapılan inceleme ve araştırmalara göre keneleri yiyen kuşların başında keklik ve sığırcık kuşları gelmektetir. Meselâ sığırcık kuşu bir günde binlerce keneyi yiyebilmektedir. ${ }^{51}$

Eğer, aşırı ve bilinçsiz avlama ve ilaçlama sonucu keneleri yiyen kuşların ölümüne sebep olanlar, Resûlullah(sav)'in şu, "kim haksiz yere bir serçeyi öldürürse, kıyâmet günü Allah onu[n hesâbını] ondan soracaktır"s2 hadisinin verdiği mesajı anlayıp gereğini icra etselerdi, fitrî dengeyi olumsuzlayan böyle bir talihsiz işe belki hiç kalkışmayacaklardı.

50 http://www.kenthaber.com/ic-anadolu/konya/Haber/Genel/Normal/bugdayi-fareleryedi/7365d1b5-668c-46a8-a7aa-e9c1559b89c9. (Erişim: 09.07.2012)

$51 \mathrm{http}: / /$ webcache.googleusercontent.com/search?q=cache:sakp6w1Hj80J:http:// www.haberler.com/kenenin-kendisi-kucuk-tehlikesi-buyuk-3667959-haberi/\%2B$\mathrm{ku} \% \mathrm{C} 5 \% 9 \mathrm{~F}+\% \mathrm{C} 3 \% \mathrm{~B} 61 \% \mathrm{C} 3 \% \mathrm{BCm} \% \mathrm{C} 3 \% \mathrm{BC}+\mathrm{kene} \& \mathrm{hl}=\operatorname{tr} \& \mathrm{gbv}=2 \& \mathrm{rlz}=1 \mathrm{~W} 1 \mathrm{GGLR}$ en\&ct=clnk, (erişim: 10.07.2012); http://webcache.googleusercontent.com/search?q=cache:ja-Mn4m_1VAJ:http://www.ardahan-cevreorman.gov.tr/kose_yazilari_ga.htm\%2B$\mathrm{ku} \% \mathrm{C} 5 \% 9 \mathrm{~F}+\% \mathrm{C} 3 \% \mathrm{~B} 61 \% \mathrm{C} 3 \% \mathrm{BCm} \% \mathrm{C} 3 \% \mathrm{BC}+\mathrm{kene} \& \mathrm{hl}=\operatorname{tr} \& \mathrm{gbv}=2 \& \mathrm{rlz}=1 \mathrm{~W} 1 \mathrm{GGLR}$ en\&ct=clnk, (erişim: 10.07.2012)

52 Suyûtî, II, 630 (hadis no., 8910). Burada şöyle bir mantık yürütülebilir: Bu hadisinde Resûlullah (sav) haksız yere serçenin öldürülmesinin yasak olduğunu beyan etmiştir. Bilindiği kadarıyla serçe, kuşların en küçük cüsseye sahip olanlarındandır. Şimdi en küçük cüsseli kuşun haksız yere öldürülmesi yasak olursa, daha büyüklerinin öldürülmesi evleviyetle engellenmelidir. Yani Hz. Peygamber bu hadisiyle bütün kuşların haksız yere öldürülmelerinin yasak olduğunu ifade etmiş olmalıdır. 


\section{Sonuç}

Yüce Allah, kusursuz ve eksiksiz bir şekilde yarattı̆̆g kâinâtı, en güzel sûrette var ettiği insanın hizmetine sunmuştur. Öte yandan bu nimetleri bir ölçüye göre verdiğini, sonsuz olmadığını, dolayısı ile onların, Kendisi'nin öngördüğü şekilde dengeli olarak kullanılması gerektiğini de bildirmiştir.

Ancak insanlar, kâinâtın paha biçilmez olan bu nimetlerini, Kur'ân ve Sünnet'in prensiplerini dikkate almadan kullanarak çevre problemine neden olmaktadırlar. Bu sorunlardan biri de hayvan avlamaktır. Kur'ân'da ve Hadiste mutlak olarak hayvan avı yapılmasına yönelik kesin bir emrin olduğunu söylemek pek mümkün görünmemektedir. Resûlullah (sav) ve ileri gelen sahâbîler hayatları boyunca avla hiç iştiğal etmemişlerdir.

Durum böyle olmakla beraber İslâm'da avın haram olduğunu söyleme imkan1 yoktur. Çünkü bu konudaki deliller böyle bir kesin hükme varmak için yeterli güçte değildir. Ancak mevcut delilleri ve dünyanın içinde bulunduğu ekolojik problemleri göz önüne aldığımızda şunu söyleyebiliriz: Hayvan avlamaya, fakirlik, açlık, kıtlık ve yokluk gibi zaruri hallerde ancak cevaz/ruhsat verilmelidir. Aksi halde hayvan avlamak, tabiî dengeyi olumsuz yönde etkileyerek çeşitli ekolojik problemlere sebebiyet vermektedir. 


\section{Kaynakça}

Castellan, A. L., Lettres sur la Grèce, I'Hellespont et Constantinople, Paris, 1811. (İsmâil Hâmi Danişmend, Garb Menbalarına Göre Eski Türk Seciyye ve Ahlakı, 3. bask1, İstanbul, 1982).

Ahmed b. Hanbel, Müsned, İstanbul, 1982.

Âsım Efendi, Kâmûs Tercemesi, İstanbul.

Beyhekî, Ebû Bekr Ahmed b. el-Huseyn b. Ali, Şu'abu'l-Îmân, (thk., Ebû Hêcir Muhammed es-Sacîd b. Besyûnî Zeğlûl), 1. baskı, Dâru'l-Kütübi'l-İlmiyye, Beyrût, 1410/1990.

Buhârî, Muhammed b. İsmâîl, el-Edebu'l-Müfred, (thk., Muhammed Fu'âd Abdulbâkî), 3. baskı, Dâru'l-Beşâ'iri'l-

Buhârî, Muhammed b. İsmâîl, Sahîhu'l-Buhârî, İstanbul, 1981.

Canan, İbrahim, Âyet ve Hadisler Işı̆̆ında Çevre Ahlakı, İstanbul, Şubat 1995.

Çobanoğlu, Nesrin, "Hayvan Haklarının Tarihsel Gelişiminin Biyoetik Yansımaları", Bilim ve Ütopya, 116. sayı, Şubat 2004.

Ebû Dâvûd, Süleymân b. el-Eşcas, Sünenu Ebî Dâvûd, İstanbul, 1981.

Ebû Yaclâ, Ahmed b. Ali el-Mevs1lî, Müsnedu Eb̂̂ Yaclâ el-Mevsllî,, (thk., Mustafa Abdulkâdir Atâ), 1. baskı, Beyrut, 1998/1418.

Fahreddîn er-Râzî, Ebû Abdillah Muhammed b. Ömer, et-Tefsîru'l-Kebîr, Daru'l-İhyâ'i't-Türâsi'l-Arabî, 3. Baskı. Hamdi Yazır, Hak Dini Kur'ân Dili, İstanbul, 1979.

Guer, Moeurset usages des Turcs, Paris, 1746-7. (İsmâil Hâmi Danişmend, Garb Menbalarına Göre Eski Türk Seciyye ve Ahlakı, 3. bask1, İstanbul, 1982).

http://webcache.googleusercontent.com/search?q=cache:ja-Mn4m 1VAJ:http://www.ardahan-cevreorman.gov.tr/kose_yazilari_ga.htm\%2B$\mathrm{ku} \% \mathrm{C} 5 \% 9 \mathrm{~F}+\% \mathrm{C} 3 \% \mathrm{~B} 61 \% \mathrm{C} 3 \% \mathrm{BCm} \% \mathrm{C} 3 \% \mathrm{BC}+\mathrm{kene} \& \mathrm{hl}=\operatorname{tr} \& \mathrm{gbv}=2 \& \mathrm{rlz}=1 \mathrm{~W}-$ 1GGLR_en\&ct=clnk, erişim: 10.07.2012.

http://webcache.googleusercontent.com/search?q=cache: sakp6wlHj80J:http://www.haberler.com/kenenin-kendisi-kucuk-tehlikesi-buyuk-3667959-haberi/\%2Bku\%C5\%9F+\%C3\%B61\%C3\%BCm $\% \mathrm{C} 3 \% \mathrm{~B}$ $\mathrm{C}+\mathrm{kene} \& \mathrm{hl}=\mathrm{tr} \& \mathrm{gbv}=2 \& \mathrm{rlz}=1 \mathrm{~W} 1 \mathrm{GGLR}$ en\&ct=clnk, erişim: 10.07.2012.

$\mathrm{http} / / / w w w . d e l i n e t c i l e r . n e t / f o r u m / e k o l o j i-v e-c e v r e-s o r u n l a r i / 127553-e k o l o-$ jik-denge-nedir.html. Erişim: 09.07.2012.

İbn Abdisselâm, Ebû Muhammed 'İzzuddîn Abdul'azîz, Kavâidu'l-Ahkâm fì 
Mesâlihi'l-Enâm, Beyrut, 1990/1410.

İbn Ebî Şeybe, Abdullah b. Muhammed, el-Müsannef fî'l-Ehâdîsi ve'l-Âsâri, (thk. ve taclîk, Secîd Muhammed el-Lehhâm), Dâru'l-Fikr, 1. bask1, Beyrut, $1409 / 1989$.

İbn Mâce, Ebû Abdillah Muhammed b. Yezîd el-Kazvînî, Sünenu İbn Mâce, İstanbul, 1981.

İbn Sîde, Ebû'l-Hasan Alî b. İsmâîl, el-Muhkem ve'l-Mühîdu'l-Azamu, (thk., Abdu'l-Hamîd el-Hindâvî), Dâru'l-Kütübi'l-İlmiyye, 1. bask1, Beyrut, $1321 / 2000$.

Kârim es-Seyyid Ğanîm, Abdulazîm Muhammed el-Cemal, el-Cerâd fí'lKur'âni 'l-Kerîm ve'l-İlmi'l-Hadîs, 1. bask1, Kahire, 1988/1409; Ahmed Behcet, Kısasu'l-Hayevân fí'l-Kur'ân, Dâruşşurûk, 4. bask1, 2000/1420.

Mouradgea d'Ohsson, Tableau Gènèral de I'Empire Othoman, Paris, 1791. (İsmâil Hâmi Danişmend, Garb Menbalarına Göre Eski Türk Seciyye ve Ahlakl, 3. bask1, İstanbul, 1982).

Mübârekfûrî, Ebû'l-'Alâ Muhammed Abdurrahmân b. Abdirrahîm, Tuhfetu'l-Ahvezî bi Şerh-i Câmici 't-Tirmizî, 1. bask1, Beyrut, 1410/1990, VI, 440.

Müslim, Ebû'l-Huseyn Müslim b. El-Haccâc, Sahîhu Müslim, İstanbul, 1981.

Nesâ'̂̂, Ebû Abdirrahman Ahmed b. Şuayb, Sünenu'n-Nesâ'̂̀, İstanbul, 1981.

Reşîd Rizâ, Muhammed, Tefsîru'l-Kur'âni'l-Hakîm eş-Şehîr bi Tefsîri'lMenâr, 2. (ofset) bask1, Dâru'l-Ma'rife, Beyrut.

Rose, Aubrey, Judaism and Ecology, (Yahudilik ve Ekoloji), (Türkçesi, Mehmet Demirhan), İstanbul, 1997.

Sungurbey, İsmet, Hayvan Haklarl, 2. bask1, İstanbul, 1993.

Suyûtî, Celâleddîn Abdurrahmân b. Ebî Bekr, el-Câmicu's-Sağîr fì Ehâdîsi'lBeşîri'n-Nezîr, Dâru'l-Fikr, 1. bask1, Beyrut, 1401/1981.

Şâh Veliyyullah ed-Dihlevî, Huccetullâhi'l-Bâliğa, (İslâm Düşünce Rehberi), (Türkçesi, Mehmed Erdoğan), İstanbul, 2003.

Taberânî, Ebû'l-Kâsım Süleymân b. Ahmed, el-Mucemu'l-Evsat, (thk., Târrk b. Ivezullah b. Muhammed - Abdulmuhsin b. İbrahim el-Huseynî), Daru'l-Haremeyn, Kahire, 1995/1415.

Taberânî, Ebû'l-Kâsım Süleymân b. Ahmed, el-Mucemu'l-Kebîr, (thk., Hamdî Abdulmecîd es-Selefî) 2. bask1, Mektebetu İbn Teymiye, Kâhire.

Tirmizî, Ebû Îsâ Muhammed b. Îsâ b. Sevrate, Sünenu't-Tirmizî, İstanbul, 1981. 
Yılmaz, İrfan, Hayvanların Dilinden, İzmir, 2005.

Yılmaz, İrfan, Hayvanlar Konuşuyor, İzmir, 2005.

Zağlûl Râğıb - Muhammed Neccâr, el-Hayevân fî̀l-Kur'âni'l-Kerîm min Âyâti'l-İccâzi'l-İlmî, Dâru'l-Ma'rife. 